(11) Nordic Council of Ministers

CLASSIFICATION AND LABELLING OF CONSTRUCTION PRODUCTS

Nordic CLP projeet 2016-2017 



\section{Classification and labelling of construction products}

Nordic CLP project 2016-2017

Alexander Kristiansen, Barbro Sillrén, Dorrit Skals, Einar Oddsson, Elisabeth Kihlberg, Gro Hagen, Jussi Ollikka and Sara Yassine

TemaNord 2017:565 


\section{Classification and labelling of construction products}

Nordic CLP project 2016-2017

Alexander Kristiansen, Barbro Sillrén, Dorrit Skals, Einar Oddsson, Elisabeth Kihlberg, Gro Hagen, Jussi Ollikka and Sara Yassine

ISBN 978-92-893-5244-4 (PRINT)

ISBN 978-92-893-5245-1 (PDF)

ISBN 978-92-893-5246-8 (EPUB)

http://dx.doi.org/10.6027/TN2017-565

TemaNord 2017:565

ISSN $0908-6692$

Standard: PDF/UA-1

ISO 14289-1

(c) Nordic Council of Ministers 2017

Cover photo: unsplash.com

Print: Rosendahls

Printed in Denmark

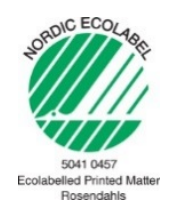

\section{Disclaimer}

This publication was funded by the Nordic Council of Ministers. However, the content does not necessarily reflect the Nordic Council of Ministers' views, opinions, attitudes or recommendations.

\section{Rights and permissions}

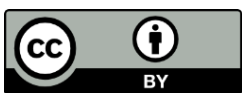

This work is made available under the Creative Commons Attribution 4.0 International license (CC BY 4.0) https://creativecommons.org/licenses/by/4.0

Translations: If you translate this work, please include the following disclaimer: This translation was not produced by the Nordic Council of Ministers and should not be construed as official. The Nordic Council of Ministers cannot be held responsible for the translation or any errors in it.

Adaptations: If you adapt this work, please include the following disclaimer along with the attribution: This is an adaptation of an original work by the Nordic Council of Ministers. Responsibility for the views and opinions expressed in the adaptation rests solely with its author(s). The views and opinions in this adaptation have not been approved by the Nordic Council of Ministers. 
Third-party content: The Nordic Council of Ministers does not necessarily own every single part of this work. The Nordic Council of Ministers cannot, therefore, guarantee that the reuse of third-party content does not infringe the copyright of the third party. If you wish to reuse any third-party content, you bear the risks associated with any such rights violations. You are responsible for determining whether there is a need to obtain permission for the use of third-party content, and if so, for obtaining the relevant permission from the copyright holder. Examples of third-party content may include, but are not limited to, tables, figures or images.

Photo rights (further permission required for reuse)

Any queries regarding rights and licences should be addressed to:

Nordic Council of Ministers/Publication Unit

Ved Stranden 18

DK-1061 Copenhagen K

Denmark

Phone +4533960200

pub@norden.org

\section{Nordic co-operation}

Nordic co-operation is one of the world's most extensive forms of regional collaboration, involving Denmark, Finland, Iceland, Norway, Sweden, and the Faroe Islands, Greenland and Åland.

Nordic co-operation has firm traditions in politics, economics and culture and plays an important role in European and international forums. The Nordic community strives for a strong Nordic Region in a strong Europe.

Nordic co-operation promotes regional interests and values in a global world. The values shared by the Nordic countries help make the region one of the most innovative and competitive in the world.

The Nordic Council of Ministers

Nordens Hus

Ved Stranden 18

DK-1061 Copenhagen K, Denmark

Tel.: +4533960200 www.norden.org

Download Nordic publications at www.norden.org/nordpub 



\section{Contents}

Preface. .7

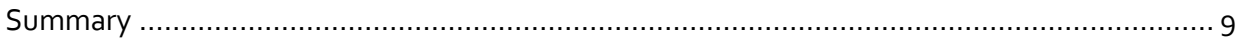

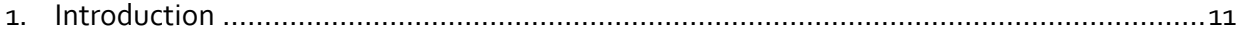

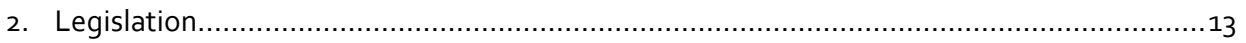

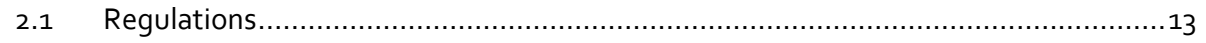

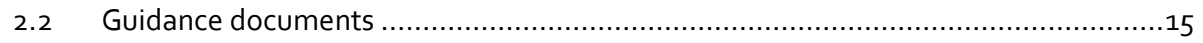

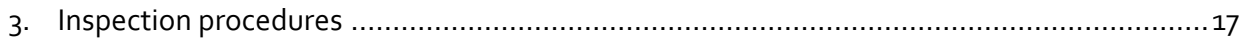

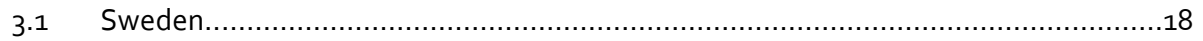

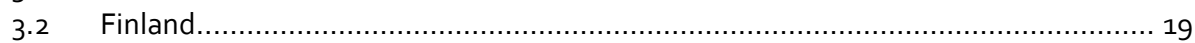

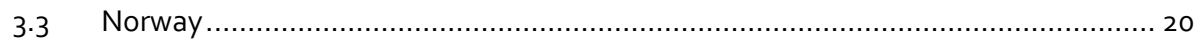

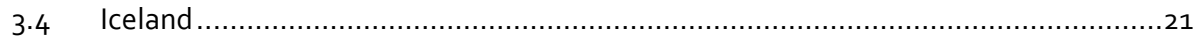

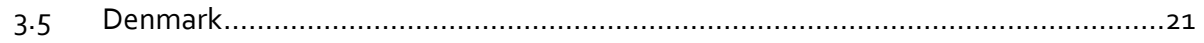

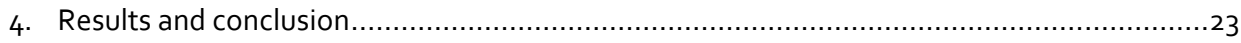

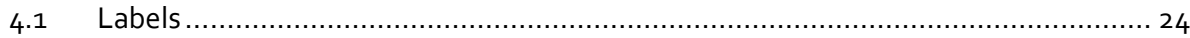

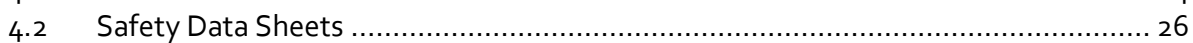

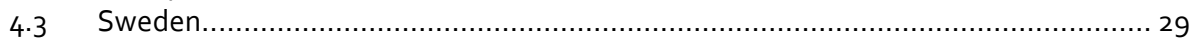

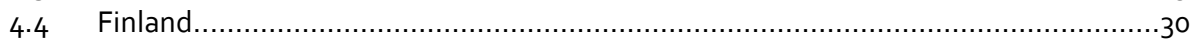

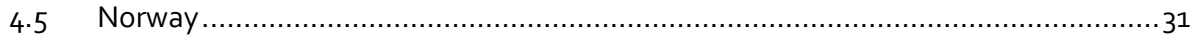

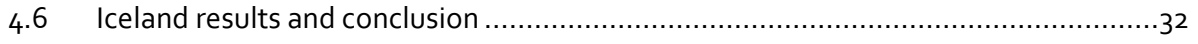

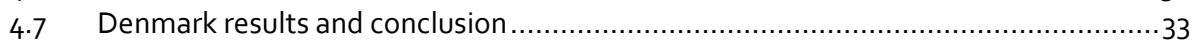

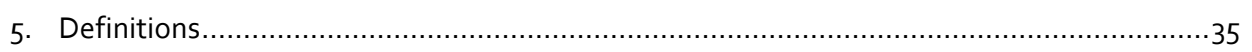

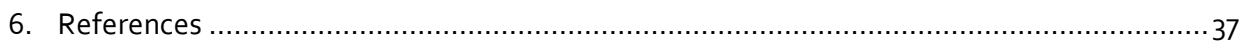

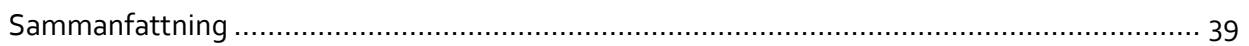

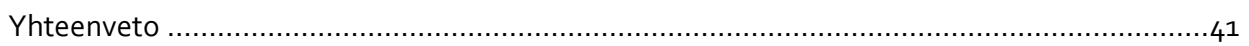

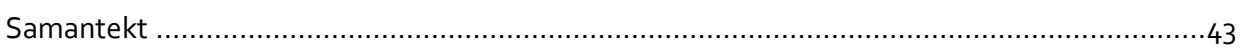

Annex: Checklist - Nordic CLP Enforcement Project 2016-2017 …................................ 45 



\section{Preface}

The chemical authorities in the Nordic countries have for many years worked together on common enforcement projects to ensure greater impact and quality in interpretation of common EU rules in the field of chemicals.

This is becoming increasingly important in relation to the many regulations which have been implemented in recent years $(C L P, R E A C H$, detergent and biocidal regulation).

The Nordic CLP Enforcement Projects are anchored in the Nordic Inspection Group, which is a subgroup under the Nordic Chemicals Group under the Nordic Council of Ministers. The main purpose of the Inspection Group is to exchange experience on inspection and enforcement of the chemical legislation and to prepare common enforcement projects. The Inspection Group meets once a year to share knowledge, discuss practical issues and exchange information from national enforcement projects.

This inspection and enforcement project was launched in 2016 and completed in 2017, and has focus on CLP classification, labelling and packaging of mixtures distributed to the general public from "Do it yourself" (DIY) warehouses and builders' merchants.

The Danish Chemicals Inspection under the Danish Environmental Protection Agency has headed the project with Sara Yassine and Dorrit Skals as project managers. Participants from the other Nordic countries in the project group have been: Alexander Kristiansen and Gro Hagen from the Norwegian Environment Agency, Elisabeth Kihlberg and Barbro Sillrén from the Swedish Chemicals Agency and Jussi Ollikka from the Finnish Safety and Chemicals Agency (Tukes) and Einar Oddsson from the Environment Agency of Iceland. 



\section{Summary}

All Nordic countries participated in this enforcement project focusing on inspecting classification and labelling of hazardous mixtures. In many cases, safety data sheets were also inspected to see whether the information in them corresponds to the label on the mixture and whether the information meets the requirements in the annex II of the REACH Regulation.

In total, 105 mixtures were inspected; primarily building products available to the general public. The result of the inspections provided a picture of the current level of quality of classification, labelling and safety data sheets now that the CLP Regulation has been fully implemented in the EU.

The main result from this CLP Enforcement Project that concerns classification and labelling was violations of Article 21 of the CLP Regulation regarding hazard statements (18\%). Other errors found concerned the application of the label, product identifier, supplemental information and signal words.

For the safety data sheets, the highest rate of violations (26\%) was observed in sections $2,3,9,11$ and 12 . Furthermore, many safety data sheets lacked sub sections (22\%). Other errors included double classification under sections $2.1,2.2$ and 3.2 in the safety data sheet.

The inspection method differs between the Nordic countries in that all countries except Sweden inspected retailers. Sweden inspected suppliers. These were mostly downstream users (formulators or distributors) of mixtures from countries outside Sweden that sell building products on the internet to private consumers.

Working together in joint Nordic CLP Enforcement Projects has great advantages as all countries have a common approach to implementing and enforcing the CLP and REACH regulations. This provides great synergy which will benefit both the Nordic authorities and the companies that place mixtures on the market in the Nordic countries.

In total, approximately 173 working days have been used in this project. 



\section{Introduction}

The current European rules on classification, labelling and packaging are contained in the CLP Regulation, which entered into force in 2010. CLP stands for Classification, Labelling and Packaging, and is based on the global GHS system (Globally Harmonized System of Classification and Labelling) established by the United Nations (UN).

The focus areas of the project were the classification and labelling of mixtures. In addition, the project included whether the information on classification and labelling on the packaging is identical to the information contained in the safety data sheet (SDS) for the mixture. Some Member States have also inspected and evaluated the total information contained in the safety data sheet for the mixture.

It was decided to limit the project so that each country inspected a total of 20 mixtures. This was sufficient to provide a picture of the quality of classification and labelling. The inspection also incorporated checking the information in the safety data sheets (SDSs) now that the CLP Regulation rules have been finally implemented in EU/EEA countries.

The investigated mixtures were marketed in builders' merchants and categorized as follows: paint, lacquer, paste, sealant and similar. 



\section{Legislation}

\section{$2.1 \quad$ Regulations}

Following regulations are relevant for this project:

- $\operatorname{CLP}(E C)$ No $1272 / 2008$

- REACH (EC) No 1907/2006, Article 31 and annex II

\subsubsection{CLP Regulation}

CLP Regulation (EC) No 1272/2008 contains rules on classification, labelling and packaging of substances and mixtures. The legislation came into force on 20 January 2009 and introduced a new system for classifying and labelling chemicals, based on the UN Globally Harmonised System (GHS). The CLP Regulation ensures that the hazards presented by chemicals are clearly communicated to workers and consumers through classification and labelling.

All substances placed on the market had to be classified and labelled according to the CLP Regulation from 1 December 2012, mixtures had to be classified and labelled according to the CLP Regulation from 1 June 2015. Mixtures classified and labelled according to the old rules and already placed on the market before 1 June 2015 did not have to be relabelled and repackaged until 1 June 2017 according to Article 61(4) of the CLP Regulation.

The suppliers of the substances and/or the mixtures are responsible for classification, labelling and packaging of the substance or mixture in accordance with the CLP Regulation and the obligations depend on their role in the supply chain:

- Manufacturer

- Importer

- Downstream user, including formulator and re-importer

- Distributor, including retailer

Importers, manufacturers and downstream users need to decide on the classification of a substance or a mixture. This is called self-classification. In some cases, the decision on the classification of a substance is taken at Community level (CLP Regulation annex VI). It is mandatory for the suppliers of the respective substance or mixture to apply this harmonised classification and labelling.

Suppliers must label a substance or mixture according to the CLP Regulation before placing it on the market either, when a substance is classified as hazardous or when a 
mixture contains one or more substances classified as hazardous above a certain limit. The CLP Regulation defines the content of the label and the organisation of the various labelling elements. The label includes:

- The name, address and telephone number of the supplier

- The nominal quantity of a substance or mixture in the package made available to the general public (unless this quantity is specified elsewhere on the package)

- Product identifiers

- Where applicable, hazard pictograms, signal words, hazard statements, precautionary statements and supplemental information required by other legislation

Classification and Labelling inventory

Classification and Labelling Inventory (C\&L Inventory) is a database which contains classification and labelling information on notified and registered substances received from manufacturers and importers. Companies have provided this information in their $C \& L$ notifications or registration dossiers. ECHA maintains the C\&L Inventory, but does not review or verify the accuracy of the information.

The C\&L Inventory also includes the list of harmonised classifications (Tables 3.1 and 3.2 of annex VI to the CLP Regulation) and the names of harmonised substances translated into all EU languages.

\subsubsection{REACH regulation}

REACH (Registration, Evaluation, Authorisation and Restriction of Chemicals) is a regulation of the European Union (EU) and the European Economic Area (EEA Norway, Iceland and Liechtenstein). REACH has been adopted to improve protection of human health and the environment from the risks that can be posed by chemicals. The regulation applies to all industry sectors dealing with chemicals and along the entire supply chain. It makes companies responsible for the safety of chemicals they place on the market.

Safety data sheets (SDSs) include information about the properties of the substance or mixture, its hazards, and instructions for handling, disposal and transport. SDSs also include first-aid, fire-fighting and exposure control measures. The format and content of SDSs are specified in Article 31 and annex II of REACH.

The last update of annex II (Regulation (EC) no. 2015/830) entered into force on 1 June 2015 and is mainly an amendment to changes made in the global harmonized system of classification and labelling of chemicals (GHS). SDSs prepared in accordance with applicable rules and delivered before 1 June 2015 could be used until 31 May 2017.

In this project, we have inspected specific sections in the SDSs which include information important for classification and labelling for a mixture: 
- Section 2 Hazard(s) identification

- Section 3 Composition/information on ingredients

- Section g Physical and chemical properties

- Section 11 Toxicological information

- Section 12 Ecological information

\subsection{Guidance documents}

ECHA compiles and publishes guidance documents for CLP and REACH. Guidance documents describe good practice on how to fulfil the obligations. They are developed with the participation of many stakeholders: industry, Member States and NGOs.

The guidance documents are available at the ECHA website:

- https://echa.europa.eu/support

The following guidance documents are relevant for this project:

- Introductory Guidance on the CLP regulation (28/08/2015) Guidance on the Application of the CLP Criteria (09/06/2015, updated 04/07/2017)

- Guidance on labelling and packaging in accordance with Regulation (EC) 1272/2008 (06/09/2016, updated 04/07/2017)

- Guidance on the compilation of safety data sheets (13/11/2015) 



\section{Inspection procedures}

The general framework for the inspections and selection of mixtures was decided at the project group meeting in April 2016. The project group consisted of representatives from all the participating countries and it was decided that each participating country would choose between 4-7 suppliers for inspection and 20 mixtures in total would be inspected per country within the following product categories:

- Paint

- Glues and adhesives

- Varnishes and lacquers

- Primers

- Cement

- Wood protection

- Sealants, putty and fillers

- Lubricants and greases

- Epoxy (paint, glue, etc.)

- Other

Countries could also inspect more mixtures if they so wished. The mixtures had to be used in the building and construction sector and meant for general consumption. It was decided that the same company could be inspected in two or more Nordic countries. The inspections were performed during the same time period (November 2016February 2017) in all the participating countries.

A web workspace called Sharepoint ${ }^{1}$ was established after the first project group meeting and it could be accessed by each country's representative. Sharepoint was intended to act as a joint working space where participants could share information on the inspection locations, information on selected mixtures and other relevant information for the project. In addition, the project group also exchanged emails about the inspections and progress of the work.

The project group decided an inspection checklist should be drafted for the inspectors in order to help in the inspection procedure and to harmonize the requirements and scope of the inspections. Denmark drafted the original document and Norway carried

\footnotetext{
${ }^{1}$ Sharepoint is a web-based workspace administrated by the Norwegian Environment Agency. The Nordic Inspection Group has established a folder in Sharepoint to which inspectors from the Nordic countries have access. Link to Nordic Sharepoint.
} 
out pilot inspections using the original form. After the pilot inspections, the finalized document was shared via the Sharepoint for all the participants.

The project group was also agreed that the companies inspected would be made aware that similar inspections were being carried out in other Nordic countries and that same general classification, labelling and safety data sheet rules apply in all Nordic countries. The companies visited were asked to check whether the mixtures being inspected were distributed in other Nordic countries and to rectify any possible errors or inconsistencies. It was hoped that this would have a spillover effect to other countries.

The results were collected from each country by using an excel-based reporting tool. Denmark drafted the reporting tool based on an excel sheet used in a previous Nordic CLP Enforcement Project.

\subsection{Sweden}

The inspections started in December 2016 and some cases are still open. Two inspectors participated in the project and inspections.

Sweden chose to combine this project with an ongoing Forum² Project. This affected the selection of mixtures, as the Forum project focused on application of Article 48(2) of the CLP Regulation and it addressed the marketing of classified mixtures to consumers.

Therefore, the selection of companies for inspection was limited to only companies that market building products to consumers via the internet. Likewise, building products exclusively for professional customers were also excluded from the selection.

The Swedish Chemicals Agency can only inspect companies which are suppliers at the start of the supply chain (e.g. formulators, distributors of mixtures from countries outside Sweden and importers that place mixtures on the Swedish market). Companies further down the supply chain, e.g. retailers, are inspected by the municipalities. The selection of companies was based on a search in the Product Register, in which all companies that formulate or import mixtures to Sweden have to be listed, as well as all mixtures in quantities exceeding $100 \mathrm{~kg}$ per year per company. Because Sweden chose to combine two projects, selection of companies was limited to companies that market directly to consumers over the internet. As some building products in Sweden are mixtures that are subcontracted from other companies, it was clear that a number of suppliers of building products (those who change the brand name) would be hard to trace in the Product Register.

In 2013 the Swedish Chemicals Agency carried out a project aimed at builders' merchants. In this project, six companies were selected that market building products in the form of mixtures, pesticides or articles. In 2015, a project was completed that focused on materials in the indoor environment with large exposure to children, such

${ }^{2}$ Forum is the Forum for Exchange of Information on Enforcement of REACH and CLP regulations. 
as flooring material. A number of companies that market building products were inspected in this project.

The Swedish Chemicals Agency conducted a wide search on the internet to find more companies. The main method was to Google companies that market building products on the internet. The search showed that by far the majority of companies that market building products on the internet are retailers. In Sweden, it is clear that only few companies are both suppliers of building products and market to consumers via the internet.

Many companies marketed their mixtures on their website, but it was not possible to purchase these mixtures via the website. Instead, the websites referred to retailers. Sometimes the customer could make a purchase list/pick list and get information if the product was in stock in the store.

Due to the limited number of companies inspected, it was decided to inspect a company with headquarters in another Nordic country. It was clear that it would be difficult to find companies for this part of the project and therefore the other Nordic countries were informed early on about the companies selected. Selections were broadened to include companies with a very wide range of mixtures, some of which are building products.

Four companies were inspected and a total of 20 mixtures. Three inspections were conducted as desktop inspections and one was selected for onsite inspection. The desktop inspections were performed by a single inspector, and the onsite inspection was performed by two inspectors. All companies received a letter informing them about the project and why they had been selected for inspection. The letter also stated the mixtures for which the companies should submit product information (labels and safety data sheet). The number of selected mixtures varied between 1 and 6 .

Inspections included checks of the classification, labelling, safety data sheets and reports to the product register. Inspections of the classification of the mixtures started with inspecting all the substances in the mixture and comparing these with the classification in the inventory to see whether they match, and also whether the composition of the mixture was reported correctly to our product register. After inspecting all the substances in the mixture, checks were made to confirm whether the mixture was classified correctly and, on the basis of the classification of the mixture, whether the labelling was correct. When this was done, checks were conducted to ensure that the sections in the safety data sheet met the requirements in annex II in REACH.

\subsection{Finland}

The majority of the inspections were done between January and February 2017. Finland inspected five builders' merchants. The inspections were done in the Greater Helsinki area and in the Greater Tampere area. Two inspectors participated in the Nordic CLP Enforcement Project from Finland. The inspections were performed by one inspector per location and the inspections were performed unannounced. The mixtures inspected were chosen at the start of the inspection. Most of the mixtures chosen belonged to the 
glues and adhesives product category. Finland did not include other national themes on the inspections.

Inspections focused on larger retailers with hardware items and mixtures used in the building and construction sector in their product ranges. Most of the household hardware used in Finland is purchased from these types of retailers. The chosen retailers were operated by Finnish companies and they represented companies with multiple locations in Finland. Some of the retailers also have their own outlets in other Nordic countries or they are affiliated with partner retailers in other Nordic countries. All the retailers inspected were also distributors.

Pictures of the mixtures inspected were taken at the inspections and the information on the label was compared to the safety data sheet information at the office.

Chosen mixtures were mainly supplied by Finnish formulators or the mixtures inspected had a Finnish EU importer. This meant that the supply chain could be influenced right at the start if significant errors were detected. Only mixtures that were classified and labelled based on the CLP Regulation were chosen, since the transitional period for mixtures classified and labelled based on the Mixtures Directive continues until June 2017 for mixtures that were placed on the market before 1 June 2015. All the mixtures inspected were for private consumption.

\subsection{Norway}

Norway decided to inspect building products available for the general public in larger builders' merchants. Builders' merchants with branches throughout Norway were preferred to give an indication of the situation for Norway in general.

Inspection objects were chosen on the basis of the general knowledge of the REACH/CLP-inspectors combined with an internet search. A list of ten inspection objects was drawn up and inspections were finally performed on five of these. Two of them were do-it-yourself (DIY) warehouses offering a variety of different product categories and the other three were mainly distributors of building products.

The inspections were performed in the Oslo area to minimize travelling time. Four of the inspections were performed by a team of two inspectors and one inspection by a single inspector. The inspections were unannounced and the inspectors contacted a supervisor when arriving at the builders' merchants. They introduced themselves and gave a short presentation of the Nordic CLP Enforcement Project. Furthermore, they informed about the practicalities and the follow-up in the event of any of noncompliance. Follow up actions were with the company responsible for distributing the non-compliant mixture on the Norwegian market.

At each retailer, the inspectors selected five to ten building products for inspection. Mixtures were chosen from several of the product categories. After the selection process, the inspectors asked the supervisor on site to provide a safety data sheet for each of the mixtures. In most cases the SDSs were printed from the builders' merchant's own web-page, but for two mixtures the SDSs were only available from the suppliers 
Inspections of labelling, classification and safety data sheets according to the checklist were performed during the inspection. A private room was made available for the inspectors for this purpose. In order to check the classification in section 2 in the SDS, inspectors used composition information from section 3 in the SDS. The inspectors used a personal computer and/or iPad to access ECHA's C\&L inventory. There were no additional national inspection themes and pictures were taken of all the mixtures.

At the end of the inspection, the inspector prepared a short summary report including a list of non-compliant mixtures. The report was signed by the inspector and given to the supervisor.

\subsection{Iceland}

The Environment Agency of Iceland (Umhverfisstofnun) inspected 20 mixtures retailed by four of the largest builders' merchants in the country. The mixtures supplied by these retailers are mostly brought into Iceland and placed on the market by the retailers themselves. Therefore, the retailers are responsible for making sure that the mixtures are labelled correctly according to the CLP Regulation and in the official language; Icelandic.

The inspections were carried out in the middle of January 2017 by two inspectors from the Agency, who at the time of inspection handed a letter of introduction to a representative of the builders' merchants. A random selection of five mixtures was made at each location and pictures were taken of the labelling for further investigation. Three of the mixtures in the sample were from an Icelandic downstream user, a company that makes paint products, but the rest were mixtures from other EEA countries placed on the market by the inspected retailers. Following the inspections, the Environment Agency requested and received safety data sheets for the sampled mixtures.

In total, the inspectors spent around 160 hours on the project. This includes preparation, the inspections themselves, investigating the data gathered, compiling a report on each inspection, sending the relevant report along with a letter of requirements to each company and verifying the companies' subsequent corrective actions. Finally, the 160 hours include making the data available for this common report as well as taking a part in writing it.

\subsection{Denmark}

In November 2016, the Chemical Inspection Service (CIS) of the Danish Environmental Protection Agency performed five unannounced inspections at selected builders' merchants in the Copenhagen area. The inspections took place at both small and large retailers of mixtures for both professional and private use. The main focus was on products for private use. 
The objective of the inspections was to select at least 20 chemical mixtures available for private use within the listed product categories in section 5 .

Prior to the inspections, the inspectors prepared an inspection letter, a sampling form and a requisition form to present to each of the stores visited. Each inspection started by contacting the responsible employee in the store. The inspector then informed the employee about the purpose of the Nordic CLP Enforcement Project and about the product collecting procedure, which was also mentioned in the inspection letter.

At the end of each inspection, information about the product identification and the contact information of the responsible supplier in Denmark was collected for further investigation. The responsible employee at each store received a completed sampling and requisition form with information about the selected products and the possibility for refund of product expenses.

When the inspections had been completed, the CIS contacted the responsible manufacturer or supplier in Denmark to request further information about the products; complete composition information in $\mathrm{w} / \mathrm{w} \%$, as well as the CAS number and Safety Data Sheets for the mixtures. 


\section{Results and conclusion}

In total, 105 mixtures were collected in the project. The mixtures were mainly building products selected from the ten product categories listed in section 5 (Inspection procedures). Mixtures were sourced from different locations such as suppliers, retailers and various types of builders' merchants, do it yourself (DIY) warehouses and web pages. The collection and inspection procedures employed varied between the Nordic countries and details can be found in the national chapters.

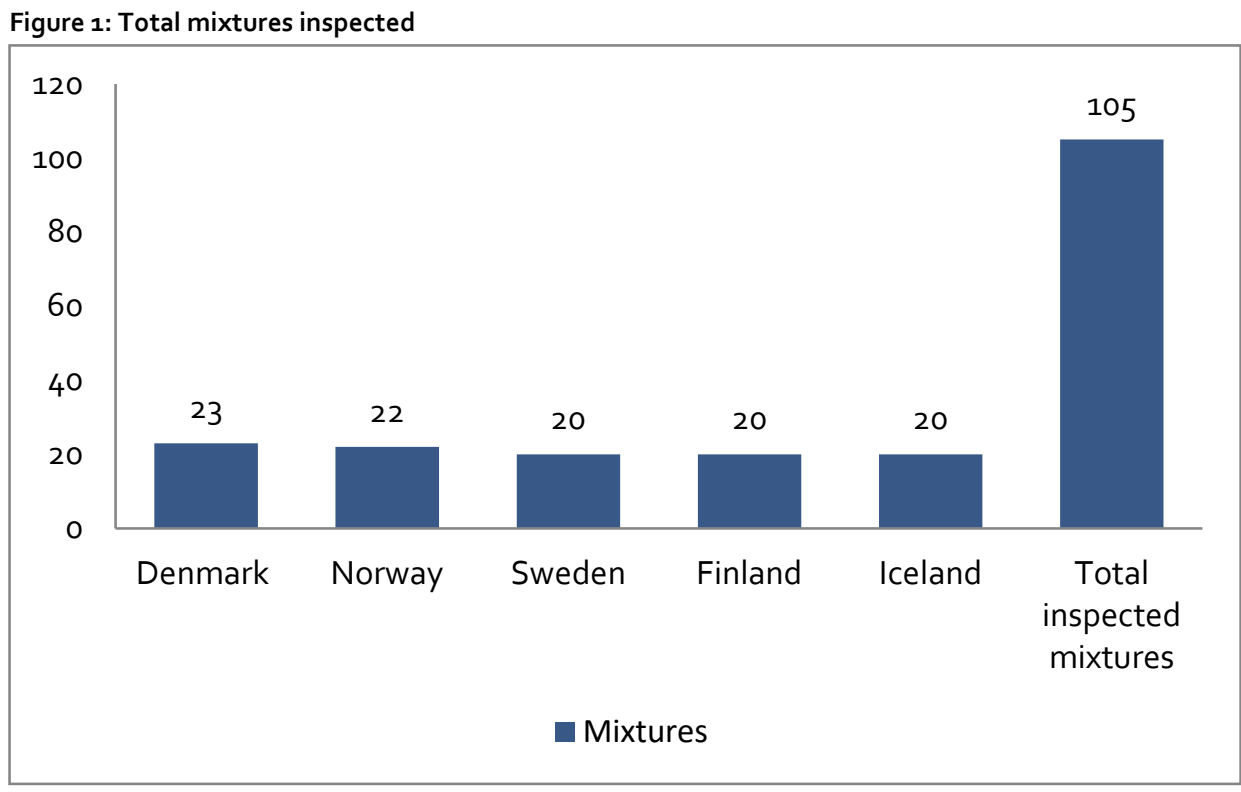

In this project, the main focus has been to ascertain how well building products available for the general public in the Nordic countries comply with the classification and labelling legislation according to Articles 17 and 25 of the CLP Regulation. Also, some sections in the Safety Data Sheets for the same mixtures were inspected for compliance with Article 31, annex II of the REACH Regulation. The sections inspected comprised sections 2 (Hazards identification), 3 (Composition/information on ingredients) and, if necessary, sections 9 (Physical and chemical properties), 11 (Toxicological information) and 12 (Ecological information).

Mixture classification and labelling according to the CLP Regulation became mandatory from 1 June 2015. For mixtures placed on the market before 1 June 2015, there was a transition period that ended on 1 June 2017, and after this all substances and mixtures on the market must be classified and labelled according to the CLP Regulation. 
The 105 building products inspected were distributed among ten product categories as shown in figure 2 . The majority of the mixtures were from the categories glues and adhesives (27\%) and sealants, putty and fillers (26\%) see figure 2 below for the distribution among the product categories.

Figure 2: Product categories distribution

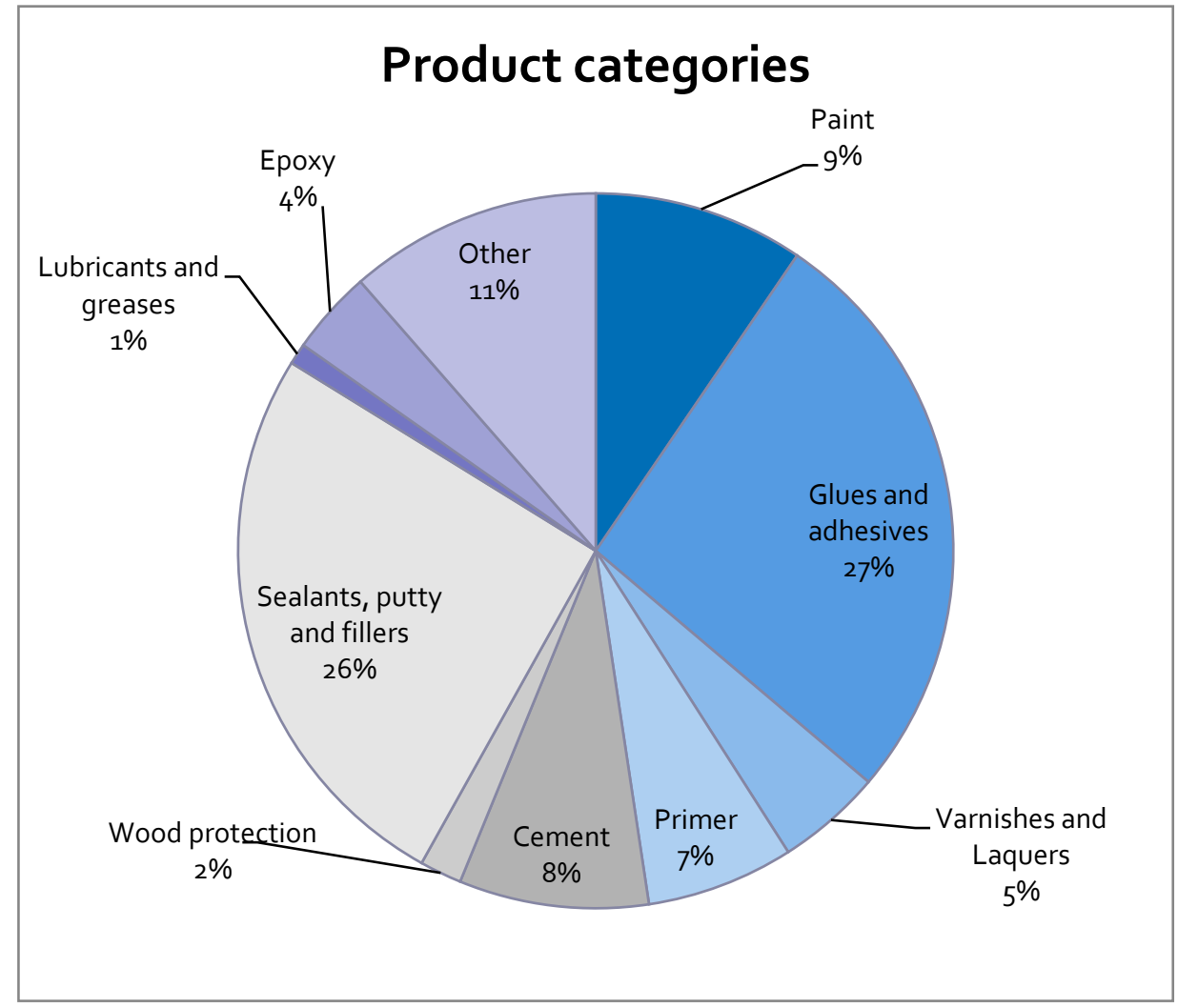

\subsection{Labels}

The labels were inspected for compliance with Articles 17 and 25 of the CLP Regulation. The overall result from the participating Nordic countries is that $46 \%$ of the 105 inspected labels contained one or more of the following errors:

- Not the correct label size

- Missing contact information

- Missing nominal quantity

- Official language

- Product identifier

- Hazard pictogram

- Signal words 
- Hazard statements

- Precautionary statements

- Supplemental information

- General rules for the application of labels

- Others

The highest error rate (18\%) was incorrect or missing hazard statements according to Article 21 of the CLP Regulation. The error types were distributed as follows:

- $14 \%$ incorrect label according the general rules for application of labels, Article 31

- $13 \%$ incorrect label according the product identifier, Article 18

- $11 \%$ incorrect label according the supplemental information, Article 25

- $11 \%$ incorrect label according to the signal words, Article 20

Nine of the 48 mixtures with incorrect labels had incorrect or missing hazard statements according to Article 21 of the CLP Regulation.

Figure 3: Distribution of labelling errors

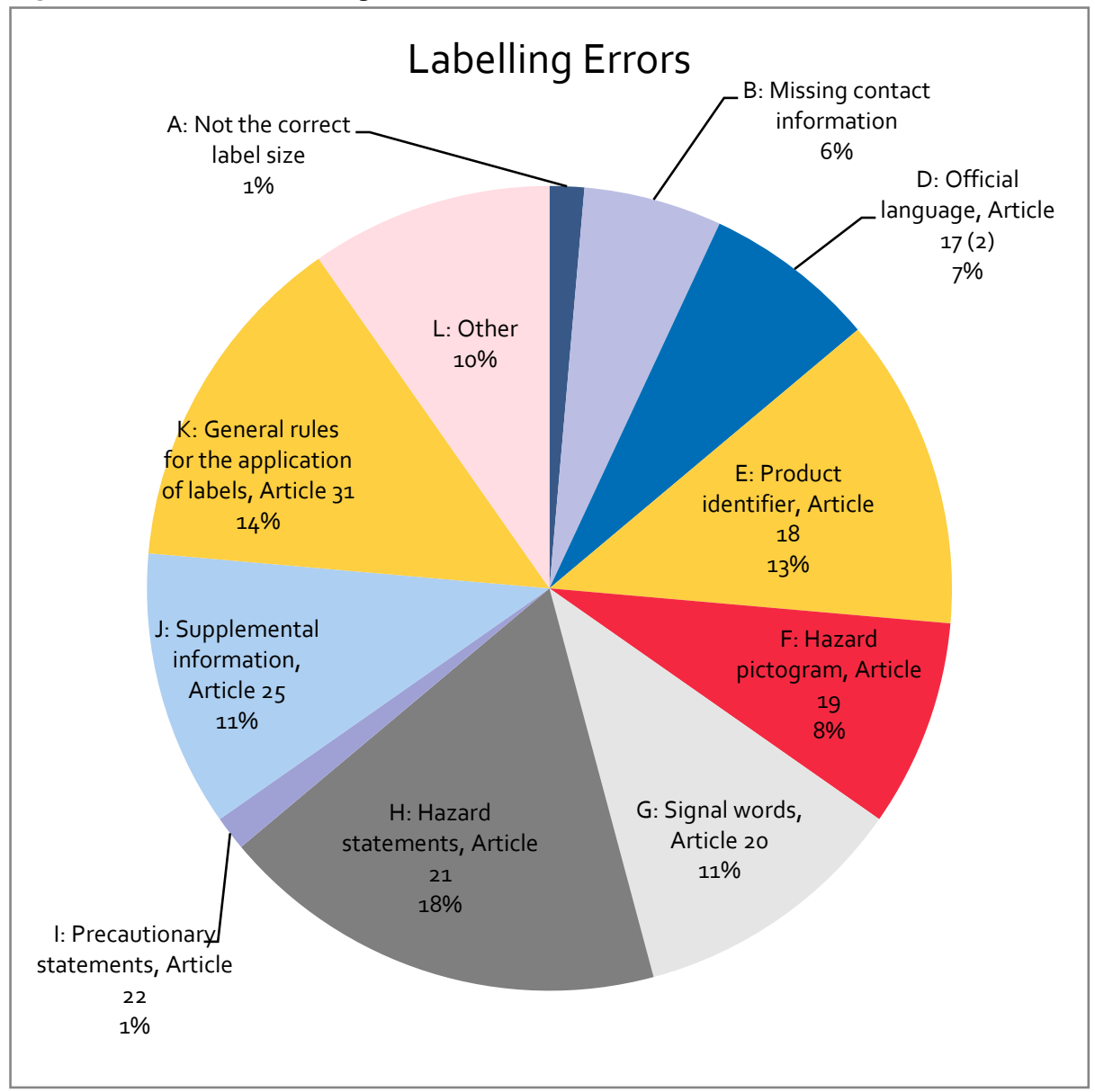


The Nordic countries differed in the practical details on how the mixtures for inspection were selected, how the conformity checks were performed and how the results were followed up. This is explained in more detail in sections 5.1 to 5.5 on how each Nordic country handled the investigation process and non-conformity regarding mixture classification, labelling and Safety Data Sheets. The most common error in the hazard labels was missing or wrong hazard statements (CLP, Article 21).

The Article 21 violations were found because of failure to update the labels and the respective SDSs, according to modified or improved mixture composition information.

The Project Group experienced that few of the observed hazard pictograms according to Article 19 had the old pictogram label. The use of old hazard pictograms on labels expired from 1 June 2017.

\subsection{Safety Data Sheets}

The Project Group ${ }^{3}$ also inspected the safety data sheets according to Article 31, annex II in the REACH Regulation. Only sections 2 (Hazard(s) identification) and 3 (Composition/information on ingredients) of the Safety Data Sheet were inspected. Information under sections 9,11 and 12 was also inspected to verify the hazard identification in section 2 .

The distribution of errors according to annex II of the REACH Regulation is illustrated at next page in figure 4 . The overall results from the participating Nordic countries show that $63 \%$ of the total 85 inspected Safety Data Sheets had one or more errors according to the Article 31, annex II of the REACH Regulation.

3 Iceland did not participate in this inspection of safety data sheets. 


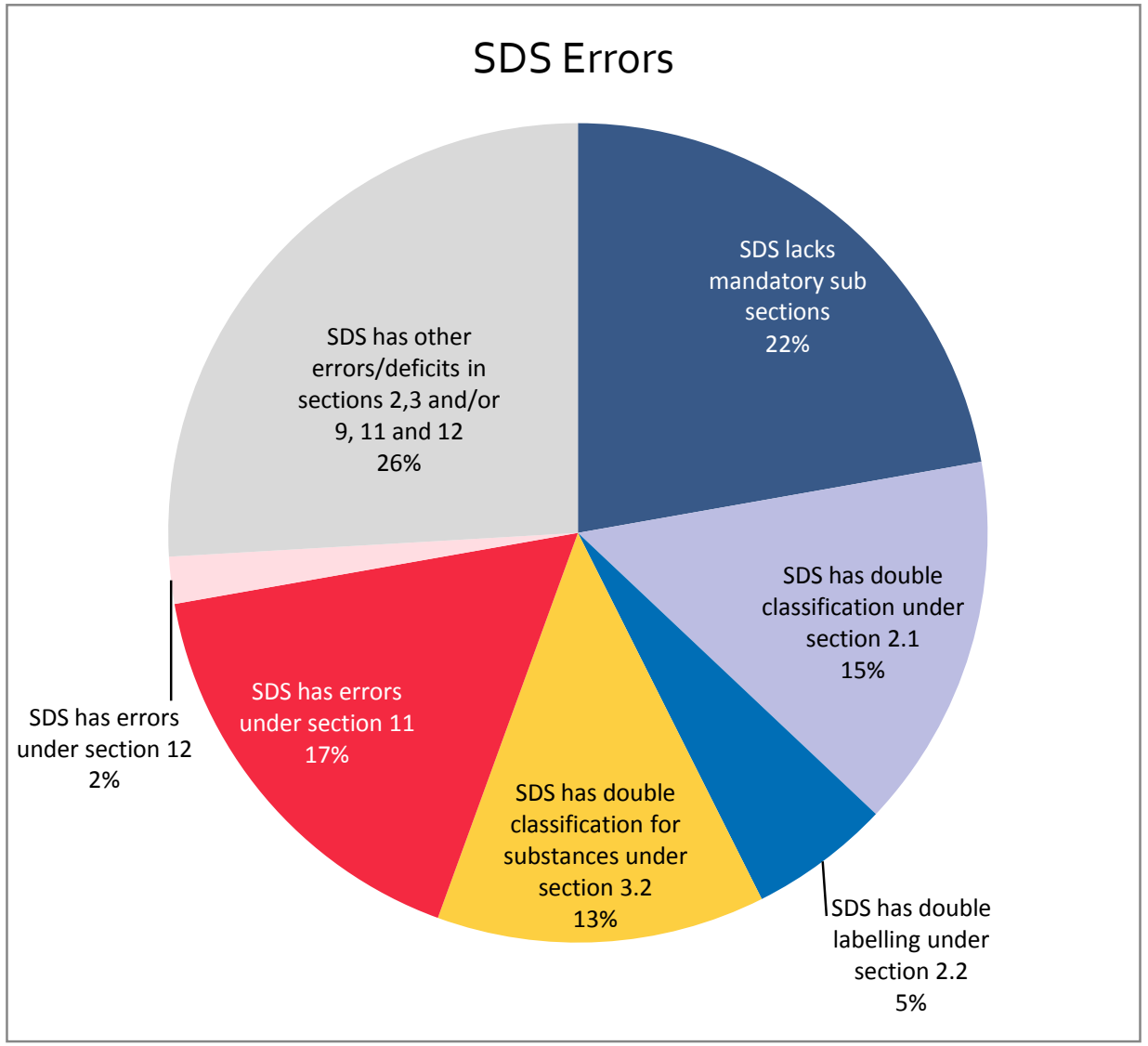

The highest non-compliance with a specific section was the lack of mandatory subsections in the SDS on the mixtures' substance information, with an error rate of $22 \%$. Second-highest non-compliance was $15 \%$ for double classification under section 2.1.

The non-compliance of $26 \%$ for other errors was under sections 2 (Hazard(s) identification), 3 (Composition/information on ingredients) and/or 9 (Physical and chemical properties), 11 (Toxicological information), and 12 (Ecological information). The non-compliance was identified as the consistency of information between different sections of the SDS and also non-compliance with the information requirements stipulated in REACH annex II.

The Safety Data Sheets were also investigated for compliance with annex VI table 3.1 - List of harmonized classification and labelling of hazardous substances in the CLP Regulation. This has been used to check that the listed substances in section 3 of the Safety Data Sheet correspond with the harmonized classification. The overall result shows that $29 \%$ of the listed substances in section 3 of the investigated Safety Data Sheets did not correspond with the harmonized classification.

This was also followed up by going through the mixtures' classification in section 2.1. Section 2.1 was inspected to ascertain whether the mixtures were correctly 
classified according to the information inspected in section 3.2. The results have been estimated and illustrated at figure 5 . It can be seen that that $20 \%$ of the Safety Data Sheets investigated were not correctly classified according to the information noted in section 3.2 .

Figure 5: Total of errors found in SDS sections 2 and 3

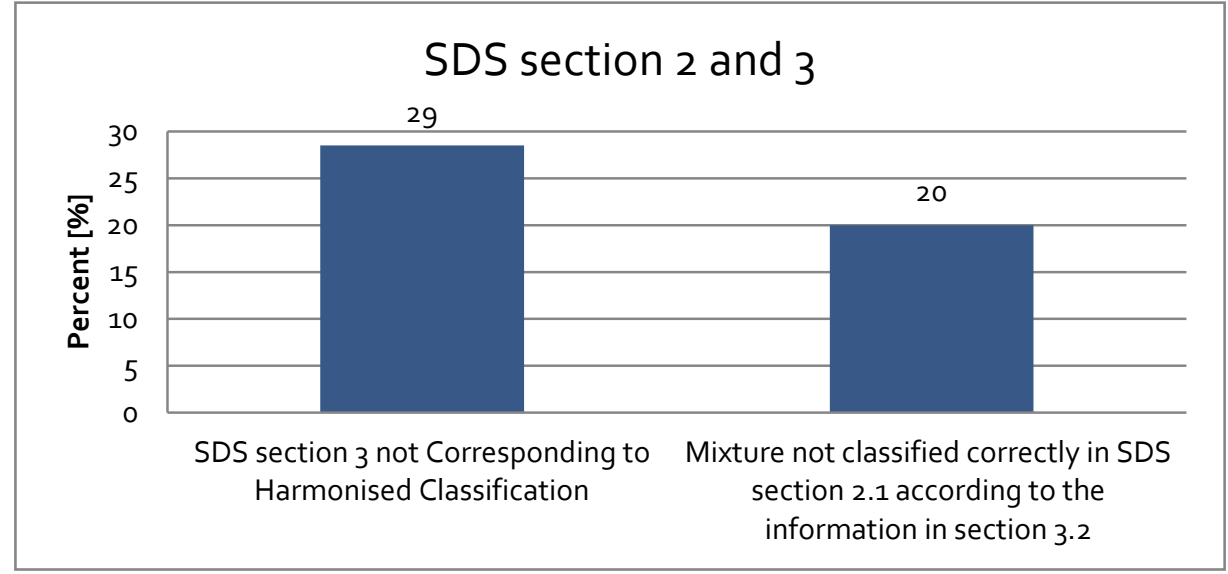

The M-factor (multiplication factor) is used to determine the mixtures' hazard classification according to the Aquatic classification. The project investigation showed that $34 \%$ of the Safety Data Sheets inspected include substances which are relevant to the Aquatic classification. The M-factor information should be mentioned at section 3 and/or 2 for these substances that contribute to the mixtures' classification.

Figure 6: Missing M-factor information in SDS

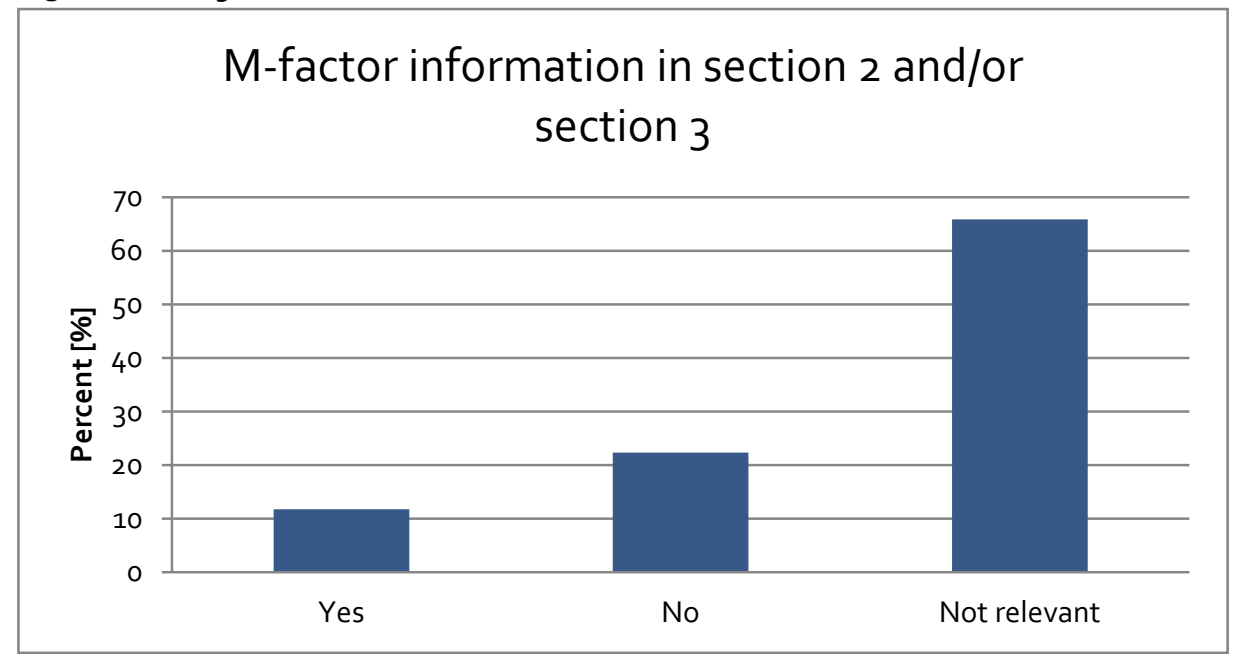


Figure 6 illustrates the distribution of whether or not the relevant M-factor information is missing. $45 \% \%^{4}$ of the relevant Safety Data Sheets inspected had correct M-factor information.

The overall project results and conclusion indicate that, although the building products inspected from the Nordic market were classified and labelled, they included many different types of errors in relation to hazard classification, hazard labelling and correct information in the Safety Data Sheet.

The most common non-compliance was labelling mixtures with an incorrect or missing hazard statement according to Article 21 of the CLP Regulation. Noncompliance with Article was the result of failure to update the labels and the respective Safety Data Sheets with modified or improved composition information.

With regard to the Safety Data Sheets, the highest non-compliance of $22 \%$ for a specific section was for failure to include mandatory subsections. Most non-compliance with multiple sections in the Safety Data Sheet was non-compliance of $26 \%$ for other error types in sections 2 (Hazard(s) identification), 3 (Composition/information on ingredients) and/or 9 (Physical and chemical properties), 11 (Toxicological information), 12 (Ecological information). This identifies a large error scope for the composition and correct content of Safety Data Sheets.

The correct M-factor information was in $45 \%$ of the Safety Data Sheets inspected. The results from an earlier Nordic project - Control of Classification and Labelling of Chemical Substances in 2012 shows a high error rate of $75 \%$ for not including the relevant M-factor information in SDS sections 2 and/or 3.

\subsection{Sweden}

The Swedish part of the project demonstrated very clearly that the building and construction market in Sweden is concentrated among only few companies. Although the building and construction market in Sweden is big in terms of economic value and quantities of mixtures, it is surprisingly homogeneous. The big companies also trade on the rest of the Nordic market.

A quick search on the internet gives the impression that there is a very large range of building products, as there are many suppliers. On closer examination, however, it becomes clear that, although there are many retailers, they are all marketing the same mixtures. The number of mixtures is therefore less than one might think, there are relatively few suppliers, and the majority of these market only to retailers. There are also different actors belonging to the same company group or are in a secondary company with another name but still part of the same group.

The conclusion was that it was not optimal to combine the Nordic CLP Enforcement Project with the FORUM project (inspecting compliance with Article 48 (2) of the CLP

${ }^{4} 12 \%$ for overall result including not relevant Safety Data Sheet. 
Regulation). What initially seemed to be an effective way to perform two projects at the same time turned out to complicate and restrict the selection of companies.

The four companies that were inspected had all been inspected at least once during the last four years, two of the companies had been inspected twice (2013 and 2015).

The companies inspected showed very good compliance with the CLP Regulation. Of a total of 20 products inspected, only five mixtures had incorrect classification (of the substance or the whole mixture) or inadequate labelling. The companies that had mixtures with incorrect classification have now corrected their classification after our inspection.

All companies are relatively large and have knowledge in-house. The relatively good result was therefore expected. The fact that all the selected companies have been inspected in recent years has probably also contributed to their good knowledge. In the previous projects there were several shortcomings, which could partly be explained by a wider scope of the inspections. Inspecting pesticides and articles (restrictions) was also a part of those projects.

As the Swedish Chemicals Agency can only inspect the suppliers of mixtures at the start of the supply chain and not e.g. retailers, the project was planned together with the municipalities concerning classification and labelling (CLP) for autumn/winter 2017. The municipalities could then inspect whether mixtures further down the supply chain meet the CLP requirements, e.g. that the mixtures are labelled according to the CLP Regulation, labelled in Swedish, have child-safe lids, etc.

Sweden used approximately 60 days for this project. Searching for mixtures and companies that are suppliers in the start of the supply chain and market mixtures to private consumers was relatively time consuming.

\subsection{Finland}

The Finnish Safety and Chemicals Agency (Tukes) inspected five retailers and also contacted the companies who supplied the mixtures to them. In more serious violations Tukes sent a formal consultation letter and for minor offences a guidance letter was sent to the supplier of the mixtures. All the suppliers initiated corrections voluntarily and no enforcement rulings were issued.

Generally, the enforcement results indicated that the majority of the inspected mixtures had some violations but these were mostly considered minor. Only a few mixtures were found with serious violations and problems with all the areas inspected of classification, labelling and Safety Data Sheet.

Safety Data Sheets were mostly drafted according to the format set in Article 31 and annex II of REACH but some deficiencies were found in the inspected sections. Of the Safety Data Sheets inspected, 16 out of 20 had some errors. Five Safety Data Sheets were not in the required language of Finnish or Swedish. The most common problem encountered was the consistency of information between different sections of the Safety Data Sheets and a few mixtures had problems with consistency between the Safety Data Sheet and label information. Mixtures inspected in Finland did not have any 
problems with providing information on the M-factors since they were not relevant for the inspected mixtures. Neither was harmonized classification an issue with the mixtures inspected.

Regarding labelling, 15 out of 20 mixtures had some errors on the labelling. Most of the encountered problems were with product identifiers, contact information and the general requirements stipulated for labels. Mixtures had substance names lacking from the label that should have been indicated in accordance with Article 18 of the CLP Regulation. General label requirements seemed to be sometimes problematic and mixtures had problems, especially with the placement of the required information in accordance with Article 31 requirements. Four inspected mixtures lacked the warning label, even though they were classified as dangerous according to the Safety Data Sheet information.

Finland used about 17 workdays in total for the Nordic CLP Enforcement Project.

\subsection{Norway}

In total, five builders' merchants and 22 mixtures were inspected, selected from the following product categories:

- Glues and adhesives (6)

- Sealants, putty and fillers (6)

- Varnishes and lacquers (3)

- Paint (1)

- Others (4)

The group others consisted of: cleaning agent (1), naphta white spirit (1), paint remover (1) and stripper for removing tapestry (1).

For the majority (16 of 22) of the mixtures inspected, correct harmonized classification was used for the substances listed in section 3 of the corresponding SDS. Likewise the majority ( 16 of 22) of the mixtures were classified correctly in section 2.1 of the SDS according to the concentration and classification of the substances listed in section 3.2 and other relevant information in sections $9,11,12$ and 16 . Of the six SDSs registered with error(s) in the classification, only two were real errors and the remaining four were registered with errors due to either old SDSs (older formats) or old classification information rendering inspection impossible.

Only six of the 22 SDSs were compiled according to REACH annex II 2015/830, the remaining being compiled in older formats. Of the six safety data sheets compiled to the newest format, three had errors. The errors in the SDSs (all formats) were mostly found in section 11. It is possible that newer SDSs do exist for some of the mixtures inspected and that the way the SDSs were collected on site has influenced this result.

$M$-factors were relevant to specify in eight of 22 SDSs, but were only provided in one of these. For the other seven SDSs M-factors were not provided in either section 2 or 3 . 
Only CLP-labelled mixtures were selected for this inspection. Only very few mixtures with old labelling were observed during the inspections. Most (15 of 22) of the selected mixtures were labelled with a label containing all mandatory information according to Articles 17 and 25 of the CLP Regulation. The remaining seven labels lacked information or contained wrong information. The most common errors found with the label were: missing product identifier (list of substances), hazard statement (wrong or missing) and general rules for application of label (does not stand out clearly; very small font size; very condensed text). Less common label errors were: missing contact information and supplemental information (missing EU sentence).

Only nine of 22 mixtures had full compliance between the hazard label and the label elements given in section 2.2 of the SDS.

Norway did not include any national inspection themes. Norway used approximately 15 working days on this project.

\subsection{Iceland results and conclusion}

Of the 20 mixtures inspected, eight had no deviation concerning labelling, five had CLP labelling in foreign languages but not in Icelandic, five mixtures had Icelandic labels according to the old regulation rather than the CLP Regulation, despite being labelled according to the CLP Regulation by the original supplier. On one mixture, the pictogram did not meet the minimum required size, another was CLP-labelled but did not have the correct hazard statements according to the relevant SDS. An overview of correctly/incorrectly labelled mixtures in each category can be found in the following graph.

Figure 7: Labelling of inspected mixtures

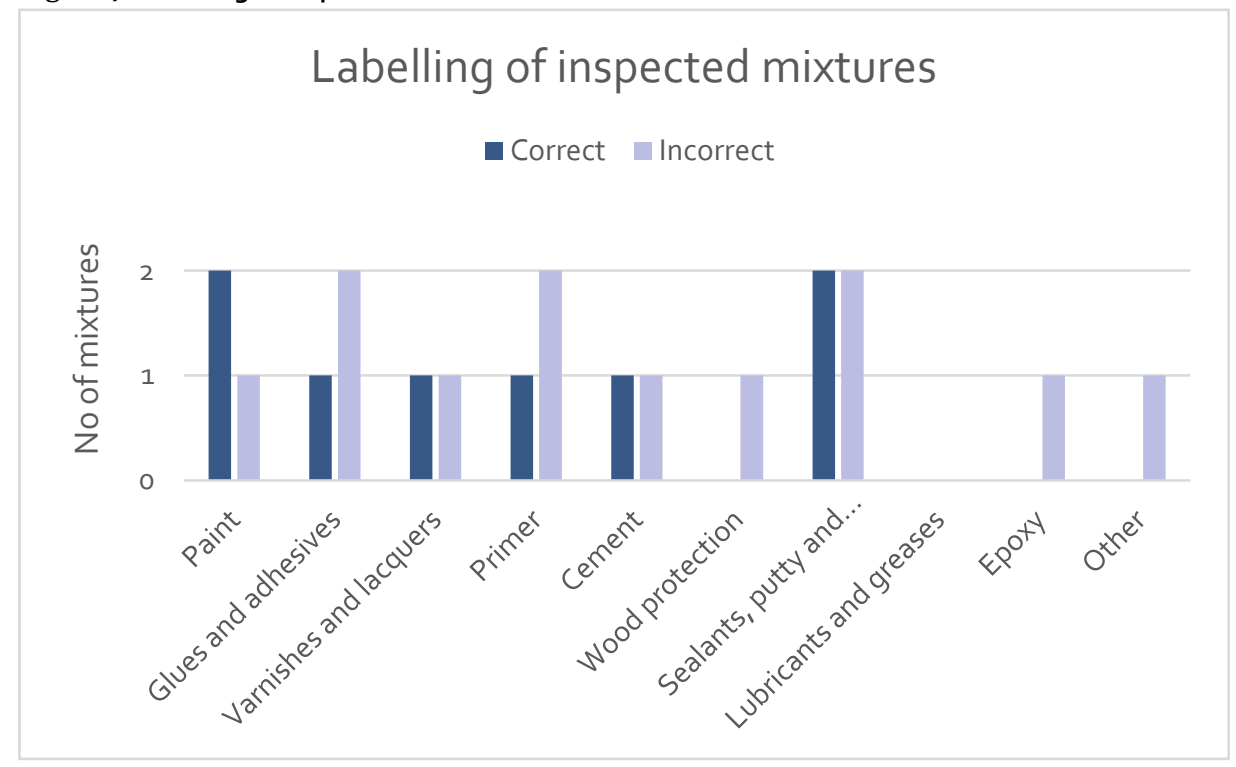


It should be noted that, due to the small population in Iceland, the labelling of hazardous mixtures in the official language of Icelandic is mostly handled by the companies placing them on the market in Iceland, rather than the original suppliers in the EEA. This is in contrast with common practice in the other Nordic countries.

In most cases where SDSs were found inadequate it was due to the fact that they were not in Icelandic. Some SDSs were in Icelandic but in need of an update. For example, in some cases the telephone number of the national poison centre was missing or an incorrect number was provided. SDSs in Icelandic are not a requirement for consumer products, but they must be supplied if requested by a downstream user or a distributor. Inspections of SDSs for mixtures in professional use are under the authority of the Administration of Occupational Safety and Health (Vinnueftirlitið) rather than the Environment Agency.

\subsection{Denmark results and conclusion}

The Chemical Inspection Service (CIS) of the Danish Environmental Protection Agency selected 23 mixtures for inspection. The mixtures were randomly selected from 16 different Danish builders' merchants.

The product inspection process was performed to check the classification and labelling of the products according to the CLP Regulation. The inspections were managed by requesting the accurate composition of the products and product information as explained in section 5.5 from the responsible product supplier in Denmark.

The information obtained was used to check whether the classification and labelling of the mixtures was correct according to Articles 17, 25 and 31 of the CLP Regulation.

Figure 8: Number of inspected mixtures distributed by the selected product categories in Denmark

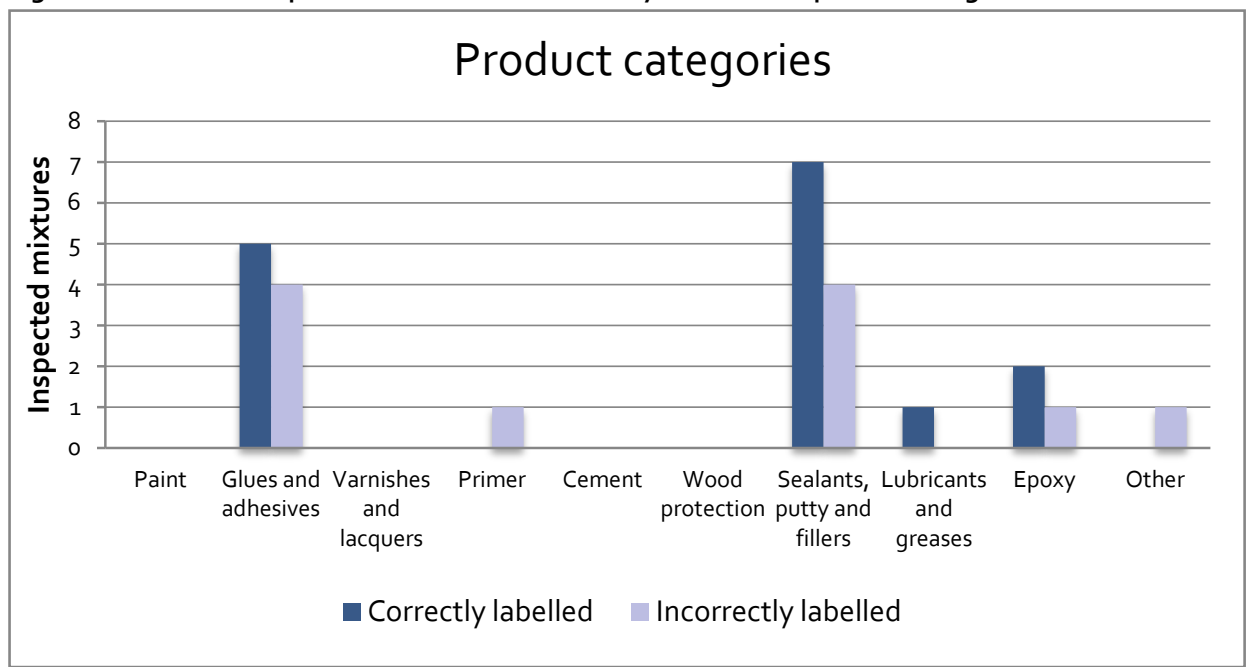


13 of the 23 products were in compliance with the CLP Regulation according the Classification and Labelling of Chemical Mixtures.

In four of the 23 products we found more than one type of error in relation to the CLP Regulation. The major types of error on the labels were the supplemental information (Article 25), hazard statement(s) (Article 21) and signal words (Article 20).

Inspections of the Safety Data Sheets (SDSs) were mostly performed according to the format set out in annex II of REACH. Errors in the SDSs were mostly found in sections 2.2 and 3.1. The most common problem was the inconsistency of information between the composition of the changed products and the Harmonized Classification in section 2.1 and 3.1. The Danish Working Environment Authority is the competent authority for inspecting Safety Data Sheets for mixtures.

In those cases where more than one error type in the same product was found, the most common reason was that the SDSs and the labels of the products were not updated according to the new formulation of the product.

Denmark used approximately 6o working days on this project. 


\section{Definitions}

The following definitions are based, to a varying degree, on official definitions found in the relevant regulations or authorities.

- CL inventory:

A database that contains classification and labelling information on notified and registered substances received from manufacturers and importers. It also includes the list of harmonised classifications (Tables 3.1 and 3.2 of annex VI to the CLP Regulation) and the names of harmonised substances translated into all EU languages.

- CLPRegulation:

Regulation (EC) No 1272/2008 on classification, labelling and packaging of substances and mixtures.

- Consumer:

A person who, acting outside the scope of industrial or professional activities, purchases goods and services.

- Downstream user:

Any natural or legal person established within the European Economic Area, other than the manufacturer or the importer, who uses a substance, either on its own or in a mixture in the course of his industrial or professional activities. A distributor or a consumer is not a downstream user.

- Distributor:

Means any natural or legal person established within the Community, including a retailer, who only stores and places on the market a substance, on its own or in a mixture, for third parties.

- ECHA:

The European Chemicals Agency, situated in Helsinki. Among ECHA's responsibilities is the coordination of the implementation of the EUs chemicals legislation.

- $E E A$ :

European Economic Area which includes EU members and Norway, Iceland and Liechtenstein.

- Harmonised classification and labelling:

When the decision on the classification of a substance is taken at Community level (CLP annex $\mathrm{VI}$ ). It is mandatory for the suppliers of the respective substance (or mixture) to apply this harmonised classification and labelling. 
- Import:

The physical introduction into the customs territory of the EEA.

- Importer:

Any natural or legal person established within the EEA who is responsible for import.

- Manufacturer:

Any natural or legal person established within the EEA who manufactures a substance within the EEA.

- M-factor:

A multiplying factor, applied to the concentration of a substance classified as hazardous to the aquatic environment acute category 1 or chronic category 1, 2 or 3. It is used to derive by the summation method the classification of a mixture in which the substance is present.

- Mixture:

A mixture or solution composed of two or more substances.

- Placing on the market/Marketing:

Supplying or making available, whether in return for payment or free of charge, to a third party. Import shall be deemed to be placing on the market.

- REACH:

Regulation (EC) No 1907/2006 concerning the registration, evaluation, authorisation and restriction of chemicals (REACH).

- Safety Data Sheet (SDS):

Data sheets containing information on the properties of substances or mixtures, potential hazards they may pose as well as information on their safe handling and disposal.

- Substance:

A chemical element and its compounds in the natural state or obtained by any manufacturing process, including any additive necessary to preserve its stability and any impurity deriving from the process used, but excluding any solvent which may be separated without affecting the stability of the substance or changing its composition.

- Supplier:

Any manufacturer, importer, downstream user or distributor placing on the market a substance, on its own or in a mixture, or a mixture. 


\section{References}

Regulation (EC) No 1907/2006 of the European Parliament and of the Council of 18 December 2006 on the Registration, Evaluation, Authorization and Restriction of Chemicals (REACH).

Regulation (EC) No 1272/2008 of the European Parliament and of the Council of 16 December 2008 on classification, labelling and packaging of substances and mixtures, amending and repealing Directives 67/548/EEC and 1999/45/EC, and amending Regulation (EC) No $1907 / 2006$.

Nordisk kjemikaliegruppe (NKG) (2013), Kontroll av klassifisering og merking av kjemiske stoffer og blandinger etter det nye CLP-regelverket Nordisk tilsynsprosjekt 2012-2013, PUB number: TN2013:565. https://doi.org/10.6027/TN2013-565 



\section{Sammanfattning}

I detta tillsynsprojekt, som fokuserat på att kontrollera klassificering och märkning av farliga blandningar, har alla nordiska länder medverkat. Även säkerhetsdatablad har kontrollerats i många fall för att se om informationen i dem stämde överens med märkningen av produkten och om bladen uppfyllde kraven i bilaga II i Reachförordningen.

Totalt har 105 blandningar kontrollerats, främst byggprodukter som har varit konsumenttillgängliga. Resultatet av kontrollerna har bidragit till att få en bild av hur klassificering, märkning och säkerhetsdatablad har slagit igenom nu när CLPförordningen gäller fullt ut inom EU.

Resultatet från projektet då det gäller klassificering och märkning rör huvudsakligen brister när det gäller angivandet av faroangivelser enligt artikel 21 i CLP (18\%). Andra brister har rört fastsättning av etiketten på förpackningen, angivande av produktbeteckning, kompletterande faroinformation samt signalord.

När det gällde säkerhetsdatabladen, så fanns de flesta bristerna (26 \%) i avsnitten 2, 3, 9, 11 och 12. Många säkerhetsdatablad saknade också de obligatoriska underrubrikerna (22\%). Andra brister som noterades var att det fortfarande fanns dubbel klassificering i avsnitten 2.1, 2.2 och 3.2 i säkerhetsdatabladen.

Inspektionsmetoderna har skilt sig åt i de nordiska länderna på så sätt att alla länder förutom Sverige har inspekterat butiker och återförsäljare. Sverige har inspekterat primärleverantörer som säljer produkter till privata konsumenter via internet, dvs. mestadels nedströmsanvändare (formulerare) och distributörer som överlåter produkter de tagit in från länder utanför Sverige.

Att arbeta tillsammans i gemensamma nordiska tillsynsprojekt har stora fördelar eftersom vi får ett mer likartat sätt att implementera och tillsyna CLP- och Reachförordningarna. Det ger därför fler synergieffekter vilket både gynnar de nordiska tillsynsmyndigheterna men även företag som sätter kemiska produkter på den nordiska marknaden.

Totalt har ca 173 arbetsdagar använts i projektet. 



\section{Yhteenveto}

Kaikki Pohjoismaat osallistuivat seosten luokituksiin ja varoitusmerkintöihin kohdistuvaan valvontaprojektiin. Myös käyttöturvallisuustiedotteita valvottiin ja tarkastettiin, että ilmoitetut tiedot vastasivat tarkastettujen kemikaalien merkintöjä sekä REACH-asetuksen liitteen II vaatimuksia.

Kaikkiaan 105 kuluttajakäyttöön tarkoitettua, lähinnä rakennusalan kemikaalia tarkastettiin. Valvontaprojektin tulos kuvastaa luokitusten, merkintöjen ja käyttöturvallisuustiedotteiden tilannetta nyt, kun CLP-asetus on lopullisesti toimeenpantu EU:ssa.

Tulokset osoittavat, että luokitusten ja merkintöjen osalta suurin osa puutteista (18\%) liittyi CLP-artiklan 21 noudattamiseen eli vaaralausekkeisiin. Muut havaitut puutteet liittyivät etiketteihin liittyviin yleisiin vaatimuksiin, tuotetunnisteisiin, täydentäviin tietoihin ja huomiosanoihin.

Käyttöturvallisuustiedotteissa suurimmat puutteet ( $26 \%$ ) havaittiin osioissa 2, 3, 9, 11 ja 12. Monesta käyttöturvallisuustiedotteesta puuttui myös pakollisia alaosioita (22 \%). Muita havaittuja puutteita olivat kaksoisluokitus kohdissa 2.1, 2.2, 3.2.

Tarkastuskäytännöt eri maissa erosivat hieman toisistaan. Pohjoismaat tarkastivat pääsääntöisesti vähittäismyymälöitä. Ruotsi kuitenkin tarkasti ensisijaisia kemikaalitoimittajia, kuten jatkokäyttäjiä tai jakelijoita, jotka tuovat kemikaaleja maahan ja myyvät niitä verkkokaupoissa yleiseen kulutukseen.

Pohjoismaisen yhteistyön kautta saavutetaan paljon etuja, koska näin yhtenäistetään eri maiden CLP- ja REACH-asetuksen valvonnan toteutusta ja valvontakäytäntöjä. Näin ollen saavutetaan synergiaetuja, jotka edesauttavat sekä Pohjoismaisia valvontaviranomaisia että yrityksiä, jotka saattavat kemikaaleja markkinoille Pohjoismaissa.

Projektin toteuttamiseen käytettiin kokonaisuudessaan noin 173 työpäivää. 



\section{Samantekt}

Öll Norðurlöndin voru pátttakendur í pessu eftirlitsverkefni, sem sneri að pví að kanna flokkun og merkingu hættulegra efnablanda. Í mörgum tilfellum voru öryggisblöð einnig til skoðunar hvað varðar samræmi milli upplýsinga á merkingum varanna og upplýsinga í öryggisblöðunum og hvort pau uppfylltu ákvæði II. viðauka við REACH reglugerðina.

Í eftirlitinu voru samtals skoðaðar 105 efnablöndur, flestar úr flokki byggingarvara á almennum markaði. Niðurstöður eftirlitsins gefa mynd af ástandi flokkunar, merkinga og öryggisblaða nú pegar CLP reglugerðin hefur verið innleidd að fullu í ESB.

Meginniðurstaða verkefnisins er að frávik frá 21. grein CLP, sem varðar hættusetningar, eru tíð (18\%). Önnur frávik sem fundust sneru að álímingu merkimiða, vörukennum, viðbótarupplýsingum og viðvörunarorðum.

Hvað öryggisblöð varðar var algengast (26\%) að frávik fyndust undir liðum 2, 3, 9, 11 og 12. Einnig vantaði undirliði i mörg öryggisblöð (22\%). Önnur frávik sneru að pví að enn má sjá tvöfalda flokkun í undirliðum 2.1, 2.2og 3.2 í öryggisblöðunum.

Algengast var að velja eftirlitspega sem eru endursöluaðilar en í Svípjóð var pó brugðið frá pví. par var farið i eftirlit hjá birgjum sem oftast voru eftirnotendur eða dreifingaraðilar vara frá öđrum löndum en Svípjóð sem selja byggingarvörur á veraldarvefnum beint til neytenda.

Samnorrænum eftirlitsverkefnum fylgir mikill ávinningur par sem pau stuðla að sameiginlegri nálgun á innleiðingu og beitingu CLP- og REACH-reglugerðanna. Með pví móti nást samlegðaráhrif sem nýtast bæði norrænum yfirvöldum og fyrirtækjunum sem markaðssetja efnablöndur á Norðurlöndum.

Samtals var varið um 173 vinnudögum í vinnslu pessa verkefnis 



\section{Annex: \\ Checklist - Nordic CLP Enforcement Project 2016-2017}

1. Information on the chemical/mixture

1.1 Country performing the control:

1.2 Date of inspection:

1.3 Name of inspector:

1.4 Place of selection/name of retail store (construction site, DIY Market, etc.):

1.5 Tradename:

1.6 Name of the company responsible for the chemical/mixture:

1.7 Contact information for the company:

1.8 Has picture been taken?

$\square$ Yes.

$\square \quad$ No

1.9 Specified REACH role:

$\square$ Manufacture/Import

$\square$ Distributor

$\square$ Downstream Users

$\square$ Other

1.9.1 Please specify if selected "other" in section 1.9:

1.10Product group:

Paint

$\square \quad$ Glues and adhesives

$\square \quad$ Varnishes and laquers

$\square$ Primer

$\square$ Cement

$\square$ Wood protection

$\square$ Sealants, putty and fillers

$\square \quad$ Lubricants and greases

$\square$ Epoxy

$\square$ Other 
1.10.1 Please specify if selected "other" in section 1.10:

1.11Additional information to section 1 (optional):

2. Control of classification

Classification of mixtures:

2.1 Does the classification of all the harmonized substances in section 3 of the SDS correspond to the harmonized classification in Annex VI table 3.1 in CLP?

Yes.

No

2.2 2.2. Is the controlled mixtures classified correctly in the SDS section 2.1 according to concentration intervals and hazard classification of substances in the SDS section 3.2, and other relevant information according to section 9, 11, 12 and 16 in the SDS?

Yes

No, the controlled mixture has a wrong classification based on the information from the classification of substances in the mixture.

2.3 Additional information to section 2 (optional):

3. Control of Safety Data Sheet (SDS)

Note to inspectors: in this project it is only relevant to control the information in sections 2 (Hazards identification), 3 (Composition/information on ingredients), and if necessary sections 9 (Physical and Chemical Properties), 11 (Toxicological information) and 12 (Ecological information).

3.1 Does the provided/inspected safety data sheet (SDS) conform to REACH article 31 and annex II. (Commission Regulation (EU) 2015/830)

Yes; SDS issue date:

No, the controlled SDS is written according to the "old" format

Yes, but the controlled SDS contains errors/deficits

3.1.1 Please specify the errors/deficits below: (Note to inspectors: products supplied before 1. June 2015 might have SDS according to older format, where duplicate DSD/CLP information might be allowed in section 2.1,

2.2 and 3.2)

SDS lacks mandatory sub sections

SDS has double classification under section 2.1

SDS has double labelling under section 2.2

SDS has double classification for substances under section 3.2

SDS has errors under section 11 (information is missing or does not correspond with the classification)

SDS has errors under section 12 (information is missing or does not correspond with the classification) 
SDS has other errors/deficits in sections 2, 3 and/or 9,11 and 12 .

3.1.2 Please specify the errors/deficits if selected "SDS has other..." in section 3.1.1:

3.2 Is the M-factors given in sections 2 and /or 3 of the SDS for those substances that are classified "Aquatic Acute 1" or "Aquatic Chronic 1"? (This is not a requirement, but it is recommended because it is important aspect in the classification of the mixture)

Yes

No

Not relevant

3.3 Additional Information to section 3 (optional):

4. Control of the hazard label

Information on the hazard label

4.1 Is the chemical/mixture labelled according to CLP?

Yes

No

4.2 Does the label of the controlled mixture have the mandatory information according to article 17 and 25 ?

Yes

No, the controlled label lacks mandatory information or has wrong information.

4.3 Please specify the errors and/or deficits below:

A. $\square$ Not correct label size

B. $\square$ Missing contact information (name, address and/or telephone number)

C. $\square$ Missing nominal quantity (only if made available for the general public and not specified elsewhere on the package

D. $\square$ Official language, article 17 (2)

E. $\square$ Product identifier, article 18 (trade name/designation and identity of all substances in the mixture that contribute to the classification of the mixture. List of hazard classes is mentioned in the article)

E.1 $\square$ Product name missing

E.2 $\square$ Listing of substances missing

F. $\square$ Hazard pictogram, article 19

F.1 $\square$ Missing

F.2 $\square$ All wrong (another shape or color as set out in section 1.2.1 in Annex I)

F.3 $\square$ Not correct size

F.4 $\square$ Other 
F.5 Please specify pictogram error:

Table 1: Minimum dimensions of labels and pictograms

\begin{tabular}{|c|c|c|}
\hline Capacity of the package & $\begin{array}{l}\text { Dimensions of the label (in } \\
\text { millimetres) for the information } \\
\text { requited by Article } 17\end{array}$ & $\begin{array}{l}\text { Dimensions of each pictogram (in } \\
\text { millimetres) }\end{array}$ \\
\hline Not exceed 3 litres: & If possible, at least $52 \times 74$ & $\begin{array}{l}\text { Not smaller than } 10 \times 10 \\
\text { If possible, at least } 16 \times 16\end{array}$ \\
\hline $\begin{array}{l}\text { Greather than } 3 \text { liters but not } \\
\text { exceeding } 50 \text { litres: }\end{array}$ & At least $74 \times 105$ & At least $23 \times 23$ \\
\hline $\begin{array}{l}\text { Greather than } 50 \text { but not exceeding } \\
500 \text { litres: }\end{array}$ & At least $105 \times 148$ & At least $32 \times 32$ \\
\hline Greather than $500:$ & At least $148 \times 210$ & At least $46 \times 46$ \\
\hline
\end{tabular}

F.6Please specify if selected "other" in section F.4.:

G. $\square$ Signal words, article 20

H. $\square$ Hazard statements, article 21

I. $\square$ Precautionary statements, article 22

J. $\square$ Supplemental information (Ex. EUH-sentences), article 25

K. $\square$ General rules for the application of labels, article 31

K.1:

The label is not firmly affixed to one or more surfaces of the packaging immediately containing the mixture

The label is not readable horizontally when the package is set down normally

The hazard pictogram does not stand out clearly on the label

The label elements from article 17 are not clearly and indelibly marked

The label elements do not stand out clearly from the background and is not easily read

L. $\square$ Other (for instance article 29, 32 and 33)

4.4 Please specify if selected "other" in section L:

4.5 Additional information (optional): 
5. Consistency between information on the hazard label and section 2.2. in the SDS (REACH annex II).

5.1 Does the hazard label of the controlled mixture correspond with the label elements in section 2.2 of the SDS?

$\square$ Yes

$\square \quad$ No, the controlled mixture has a different hazard labelling compared to the corresponding SDS

5.2 Additional information (optional): 
Nordic Council of Ministers

Nordens Hus

Ved Stranden 18

DK-1061 Copenhagen K

www.norden.org

\section{CLASSIFICATION AND LABELLING OF CONSTRUCTION PRODUCTS}

The chemical authorities in the Nordic countries (Denmark, Finland, Iceland, Norway and Sweden) have participated in this enforcement project focusing on inspecting classification and labelling of construction products according to the CLP (Classification Labelling and Packaging) regulation. The safety data sheets were also inspected according to annex II of the $\mathrm{REACH}$ regulation. 